EGU2020-14026, updated on 08 Dec 2020

https://doi.org/10.5194/egusphere-egu2020-14026

EGU General Assembly 2020

(c) Author(s) 2020. This work is distributed under

the Creative Commons Attribution 4.0 License.

\title{
Understanding soil profiles and sediment redistribution over long time scales in an agrarian setting: the case of Lauwerdal (Northern France)
}

\author{
Nick Krekelbergh ${ }^{1}$, Amaury Frankl${ }^{2}$, and Stefaan Dondeyne ${ }^{3}$ \\ ${ }^{1}$ Ghent University, Faculty of Bioscience Engineering, Environment, Belgium (nick.krekelbergh@ugent.be) \\ ${ }^{2}$ Ghent University, Faculty of Sciences, Geography, Belgium (amaury.frankl@ugent.be) \\ ${ }^{3}$ Ghent University, Faculty of Sciences, Geography, Belgium (stefaan.dondeyne@ugent.be)
}

Soil erosion constitutes a major problem in the European loess belt. From England to Eastern Europe, loess-derived soils are particularly susceptible to water and tillage erosion. This is certainly the case for the Aa River Basin (Nord-Pas-de-Calais, northern France), where a relatively thin Pleistocene loess cover is present on top of a substrate of clay-with-flints and Cretaceous chalk. This research aimed at quantifying the amount of soil eroded since its initiation. Making a gross balance of the soil erosion and sedimentation processes intends to study the evolution of the soil surface and the effects of different types of erosion over longer periods of time, and quantify erosion rates in agricultural areas.

The extent and amount of eroded soil was mapped in the Lauwerdal, a 63 ha large catchment in the headwaters of the Aa River Basin (Northern France). Based on four soil profiles, described and sampled along a topographic transect, and 256 augerings spaced along a grid, the original soil surface level was reconstructed. The current topographic surface was analysed based on a Digital Terrain Model obtained from UAV aerial photographs. The organic matter present in the filling of a former erosion channel, observed in one of the soil profiles, was dated by ${ }^{14} \mathrm{C}$ as an indication of the onset of the erosion and sedimentation process.

Water and tillage erosion are the main processes characterizing the study area: eroded soils (Nudiargic Luvisols) dominate the upper reaches of the study area with colluvium at the footslopes (Colluvic Regosols). The sediment budget reveals that the bulk of the sediments are discharged from the headwater catchment as the quantity of eroded soil $\left(0.87 \times 10^{6}\right.$ tonnes $)$ is more than a ten-fold higher than the deposition $\left(0.068 \times 10^{6}\right.$ tonnes). The ${ }^{14} \mathrm{C}$ dating indicates that the erosion channels started filling up between the Early Iron Age and the Roman period, ca. 1200 years BP. The historical erosion rates are estimated at $491.4 \mathrm{t} / \mathrm{km}^{2}$ per year, and deposition rates at 91.8 $\mathrm{t} / \mathrm{km}^{2}$ per year.

Our findings illustrate how the amount of soil eroded over a long time span can be estimated from soil morphologic features in combination with a detailed Digital Terrain Model. Indeed, human induced soil erosion dates back at least to Early Iron Age, when forest clearing for agricultural 
expanded. Surely, the mechanization and upscaling of agriculture in the $20^{\text {th }}$ century will have exacerbated this process. The results also show that sediments are evacuated from headwater catchments and, consequently, must accumulate in the lower alluvial plains. Our findings corroborate research findings from the silt-loess belt of central Belgium where it was shown that soil erosion started in the same period and also led to the formation of wide alluvial valleys. 